\title{
Characterisation and quantification of mucosal cytokine that induces epithelial histocompatibility locus antigen-DR expression in inflammatory bowel disease
}

\author{
J R Lowes, P Radwan, J D Priddle, D P Jewell
}

\begin{abstract}
Epithelial histocompatibility locus antigen (HLA) class II expression was studied to evaluate its induction by mucosal mononuclear cells in inflammatory bowel disease and to characterise the responsible cytokine. Unstimulated cells of the HT-29 epithelial cell line did not produce class II molecules. After being stimulated with the mitogenic lectin phytohaemagglutinin mucosal mononuclear cells released a cytokine that induced epithelial HLA-DR expression. The cytokine had the physicochemical and immunological characteristics of interferon- $\gamma$, and no additional cytokines were detected.
\end{abstract}

The expression of major histocompatibility complex antigen-class II molecules by non-lymphoid cells is well recognised..$^{1-4}$ The function of these molecules remains the subject of debate. ${ }^{5}$ It has been claimed that epithelial cells expressing class II histocompatibility molecules can act as antigen presenting cells to $\mathrm{T}$ cells.$^{67}$ It has been suggested that normally, epithelial cells present antigen to $\mathrm{CD} 8+$ antigen specific suppressor cells, ${ }^{8}$ or antigen non-specific suppressor cells. ${ }^{6}$ Normal murine enterocytes however, have been shown to present soluble antigen in a class II restricted fashion to an antigen specific $\mathrm{T}$ cell hybridoma producing interleukin-2. ${ }^{9}$

Mayer has further shown that enterocytes from idiopathically inflamed intestine may support the proliferation of CD4 + cells unrelated to the level of HLA-DR expression, and suggest that in idiopathic inflammatory bowel disease there is an inability to present antigen to antigen non-specific $T$ suppressor cells. ${ }^{10}$ In inflammatory bowel diseases such as ulcerative colitis and Crohn's disease there is evidence of activation of immunological effector mechanisms in the mucosa. ${ }^{11}$ It is not clear if the activated immunological processes are an appropriate response to an as yet unidentified pathogen or a pathologically increased response to a relatively otherwise innocent challenge. An increase in colonic epithelial cell class II histocompatibility locus antigen expression has been noted in both ulcerative colitis and Crohn's disease when in relapse. $^{212-1+}$ If these cells act as antigen presenting cells they may amplify the mucosal immune response by increasing antigen presentation to the mucosal and intraepithelial $\mathrm{T}$ cell population. It is likely that epithelial cell class II histocompatibility antigen expression is induced by cytokines acting in a paracrine fashion in the lamina propria. ${ }^{3}$ From animal experimentation, interferon $\gamma$ is a possible candidate. ${ }^{15}$ We have examined the mucosal mononuclear cell population looking for evidence of cytokines that induce epithelial cell class II expression and the hypothesis that there is increased production in ulcerative colitis and Crohn's disease.

\section{Methods}

\section{PATIENTS}

Fresh surgical specimens were obtained from patients undergoing intestinal resection for active ulcerative colitis $(n=13)$, Crohn's disease $(n=5)$ (ileocaecal resections), colonic neoplasia or chronic constipation $(n=11)$. Patients with inflammatory bowel disease had failed medical treatment for acute relapses of disease. Mucosa from macroscopically inflamed and non-inflamed sites was compared in specimens from patients with distal ulcerative colitis. In patients with colon cancer, mucosa was taken $>5 \mathrm{~cm}$ from tumour. Histological sections from adjacent mucosa confirmed macroscopic and clinical diagnoses. Patient details are listed in the Table.

ISOLATION OF MUCOSAL MONONUCLEAR CELLS Mononuclear cells were isolated by a modification of the method of Bookman and Bull. ${ }^{16}$ Briefly, the resection specimen was immediately placed in RPMI 1640 medium at $4^{\circ} \mathrm{C}$ and transported to the laboratory. Mucus was scraped from the surface of the specimen during three washes in Hank's balanced salt solution without calcium and magnesium (HBSS-CMF). Strips of mucosa were then placed in $1 \mathrm{mM}$ dithiothreitol for 15 minutes at room temperature to further remove mucus. Epithelial cells were removed by three incubations at $37^{\circ} \mathrm{C}$ in $5 \mathrm{mM}$ EDTA in a shaking water bath. The mucosal strips were minced and

TABLE I

\begin{tabular}{lllll}
\hline Disease & $n$ & M:F & $\begin{array}{l}\text { Median } \\
\text { (range) } \\
\text { Age }\end{array}$ & Therapy \\
\hline UC & 13 & $9: 4$ & $42(17-65)$ & IV Steroids \\
$\begin{array}{c}\text { Crohn's } \\
\text { disease }\end{array}$ & 5 & $3: 2$ & $40(15-60)$ & $\begin{array}{l}\text { IV steroids } \\
\text { (except 1) }\end{array}$ \\
Control & 11 & $8: 3$ & $64(50-77)$ & Nil \\
\hline
\end{tabular}

Gastroenterology Unit Actication 
incubated for three hours in collagenase $(3 \mathrm{mg} / \mathrm{ml})$ (Boehringer, Mannheim GmbHW, Germany) at $37^{\circ} \mathrm{C}$. The digest was filtered through a $200 \mu \mathrm{m}$

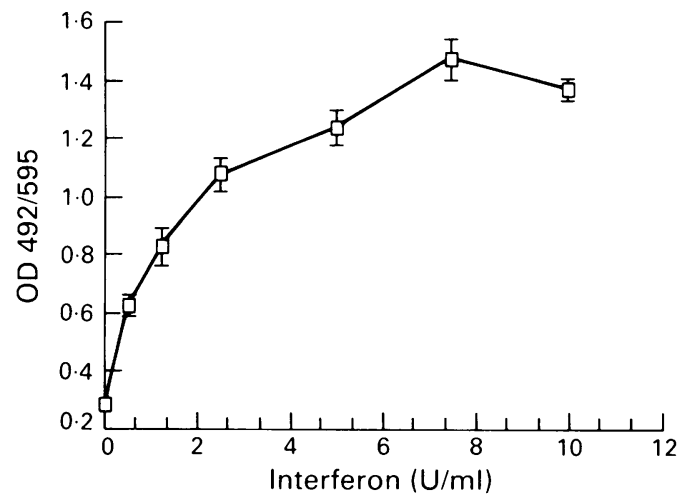

Figure 1: ELISA quantification of $H L A-D R /$ cellular protein $(S D)$ by interferon- $\gamma$ (Each point represents the mean of five observations)
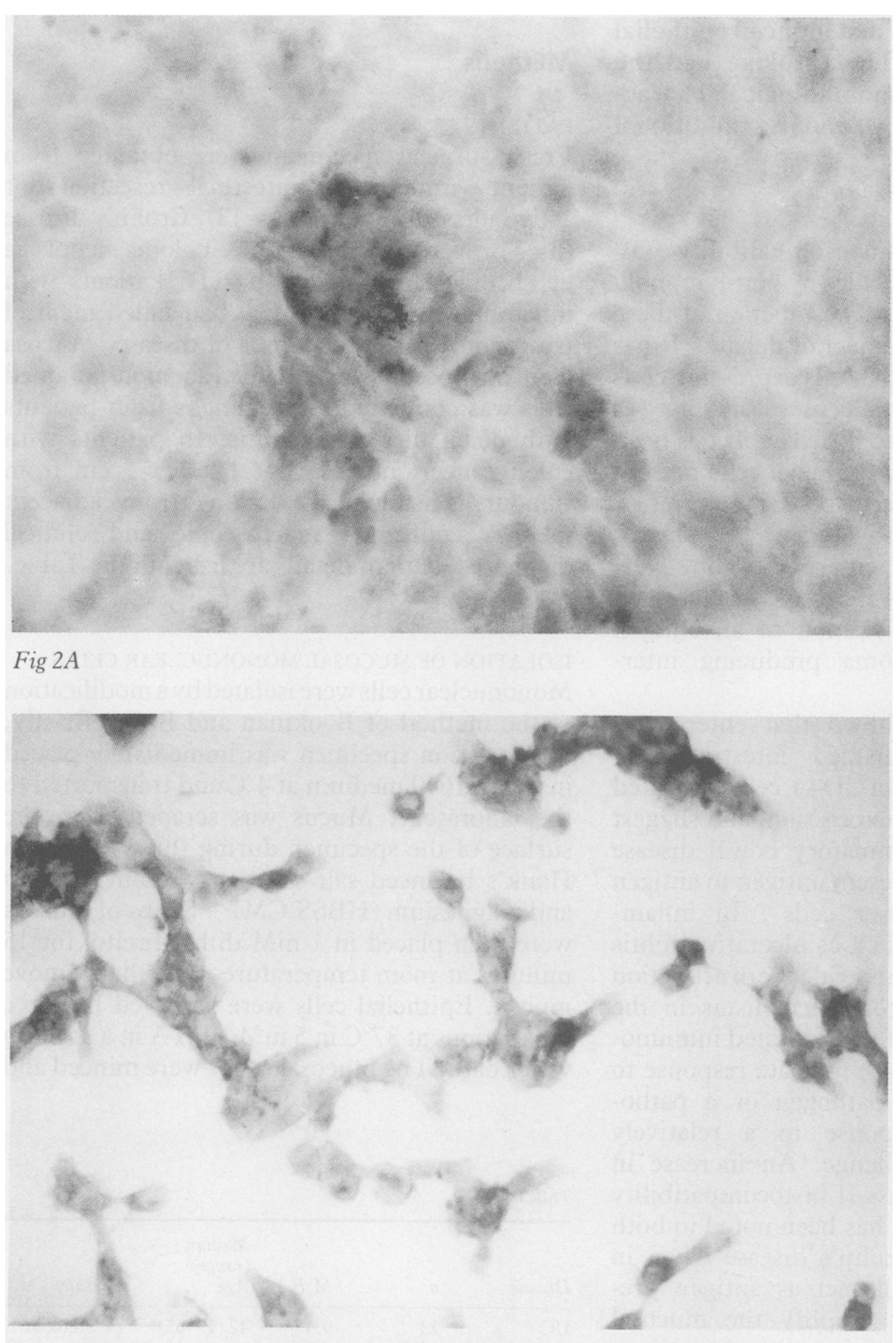

Figure 2: Immunohistochemical quantitation of HLA-DR on HT-29 cells (a) $5 \mathrm{U} / \mathrm{ml}$ interferon- $\gamma$. Many of the cells are $H L A-D R$ positive. (b) $50 \mathrm{U} / \mathrm{ml}$ interferon- $\gamma$. The majority of the cells are HLA-DR positive. A significant cytopathic effect is observed. mesh and viability of the cell suspension calculated using trypan blue exclusion. After 'Ficolpaque' (Pharmacia, UK) density gradient centrifugation, the resulting cell suspension was washed and resuspended at $10^{6}$ viable cells $/ \mathrm{ml}$ in RPMI 1640, $10 \%$ foetal calf serum. The cells were then cultured for $72 \mathrm{~h}$ (10) $\mu \mathrm{g}$ phytohaemagglutinin at $37^{\circ} \mathrm{C}$ in 24 well plates in a humidified incubator using $10 \mathrm{mM}$ Hepes, or $5 \%$ $\mathrm{CO}_{2}$ as buffer. Supernatants were harvested and filtered through a $22 \mu \mathrm{m}$ filter (Acrodisc, Gelman Scientific). Supernatants were stored at $-20^{\circ} \mathrm{C}$ for future testing.

EPITHELIAL CELL LINE

The human colonic cancer cell line HT-29 was used (Courtesty of Dr P Brandtzaeg, Oslo, Norway). This was grown in Leibowitz-15 medium supplemented with $10 \%$ fetal calf serum, $2 \mathrm{mM}$ glutamine, and gentamicin and amphotericin (Complete Medium).

\section{INTERFERON- $\gamma$}

Recombinant interferon- $\gamma$ (courtesy of Dr G Scott, Wellcome Biotechnology, Beckenham Kent) was used as a standard in concentrations up to $10 \mathrm{U} / \mathrm{ml}$ after pilot experiments had shown that up to this concentration induced maximal HLA-DR induction on HT-29 and that higher concentrations had a marked cytopathic effect without further increasing HLA-DR induction.

\section{EPITHELIAL HLA-DR INDUCTION}

HT-29 cells were seeded at $2 \times 10^{5} / 200 \mu \mathrm{l} /$ well into 96 well plates (Linbro, Flow Laboratories). After $24 \mathrm{~h}$ the cells are adherent and entering the logarithmic phase of growth, the medium was discarded and replaced with $150 \mu$ l complete medium and $50 \mu \mathrm{l}$ interferon solution (in RPMI $1640,10 \%$ fetal calf serum) or test supernatant. The cells were cultured for a further $48 \mathrm{~h}$ at $37^{\circ} \mathrm{C}$ before assay. In all experiments employing mononuclear cell supernatants, interferon standards were employed in order that interassay variation could be eliminated. HLA-DR induction could then be expressed as interferon$\gamma$ equivalent units.

\section{ANTIBODY TO HLA-DR}

A monoclonal antibody to a non-polymorphic component of the $\beta$ chain of the human HLADR molecule was used (Dako, High Wycombe).

\section{IMMUNOPEROXIDASE STUDIES}

Cells were cultured on plastic cover slips (Thermanox UK) for 72 hours with $0-500 \mathrm{U} / \mathrm{ml}$ interferon- $\gamma$. Washed three times with Hank's balanced salt solution, air dried, and fixed in absolute ethanol. Endogenous peroxidase activity was blocked by the addition of $3 \%$ hydrogen peroxide in phosphate buffered saline. The slides were washed and incubated for 30 mintues in swine serum diluted 1:5 with phosphate buffered saline. The slides were incubated for 30 minutes with $30 \mu \mathrm{l}$ HLA-DR monoclonal 


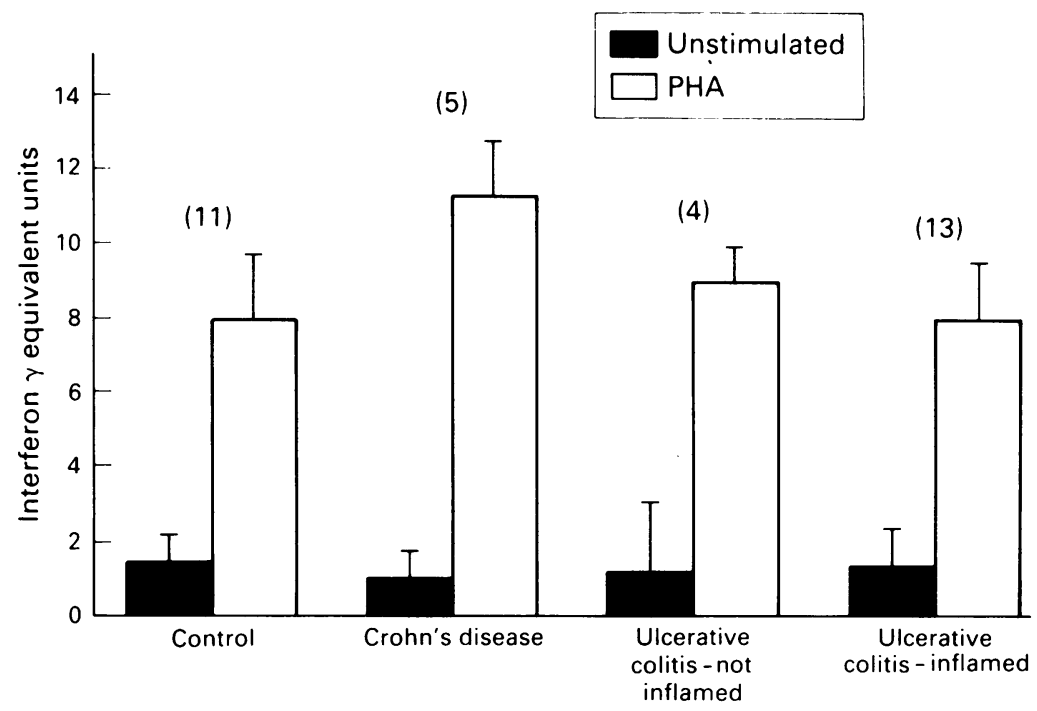

Figure 3: Interferon- $\gamma$ equivalents $(S D)$ produced by culture supernatants of resting and phytohaemagluttinin stimulated mucosal mononuclear cells.

antibody diluted 1:5 in phosphate buffered saline and washed. Peroxidase conjugated rabbit antimouse immunoglobulin was added diluted $1: 100$ in phosphate buffered saline, incubated for 30 minutes. Diaminobenzidine tetrahydrochloride (BDH, Poole, Dorset) was used as the peroxidase substrate.

\section{HLA-DR ENZYME LINKED IMMUNOADSORBENT ASSAY (ELISA)}

At the end of the culture period the cells were washed three times in phosphate buffered saline $0 \cdot 13 \mathrm{M} \mathrm{pH} 7 \cdot 3$ at room temperature and the cells air dried at $37^{\circ} \mathrm{C}$ for three to six hours fixed using $200 \mu \mathrm{l}$ methanol (AnalaR, BHD, Poole, UK.) and endogenous peroxidase activity was blocked with $1 \%$ hydrogen peroxidase. Non-specific binding sites in the wells were blocked by incubation with $200 \mu \mathrm{l} 1 \%$ gelatin (porcine skin, Sigma, Poole, UK) containing $80 \mu \mathrm{g}$ heat aggregated rabbit immunoglobulin (Dako, High Wycombe) for two hours at room temperature.

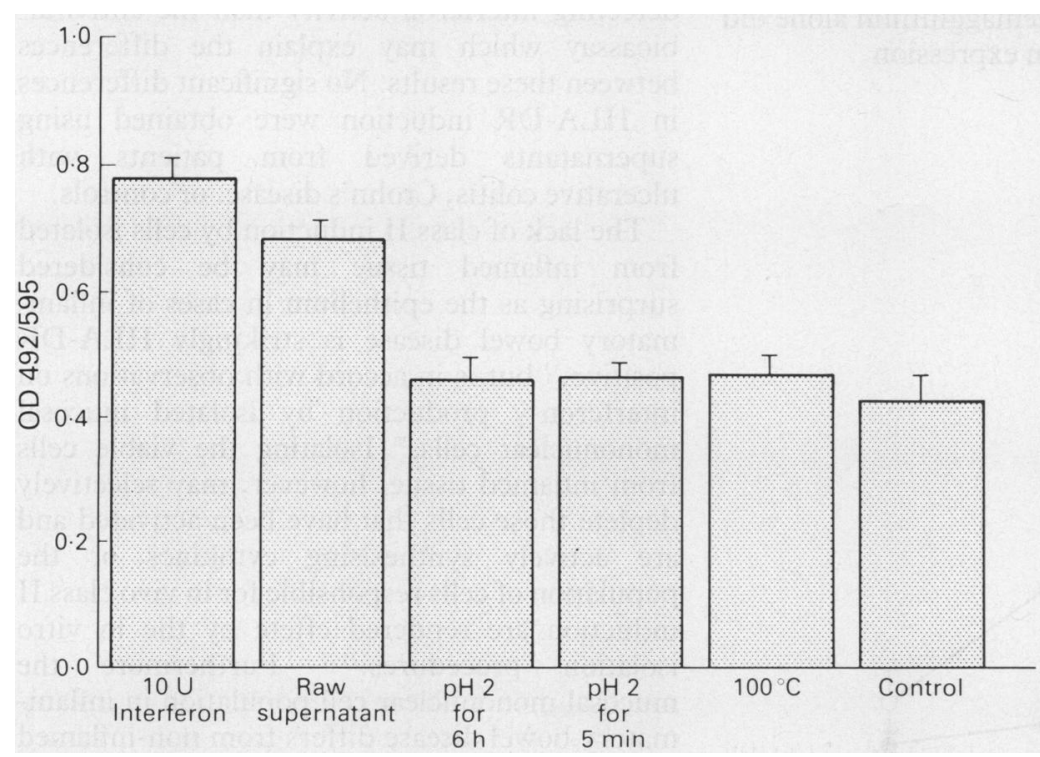

Figure 4: Effects of various physicochemical treatments of culture supernatants on HLA$D R$ induction.
The monoclonal antibody to HLA-DR was used as a 1:50 dilution of a culture supernatant. Each well was incubated with $100 \mu \mathrm{l}$ antibody at $4^{\circ} \mathrm{C}$ for 16 hours in a humidified chamber. The plates were washed four times with $0 \cdot 1 \%$ gelatin in phosphate buffered saline (Wash solution, $\mathrm{pH}$ $7 \cdot 3,0.13 \mathrm{M})$ and incubated for one hour with peroxidase conjugated rabbit antimouse antiserum (Dako, High Wycombe, Bucks). The plates were washed four times with wash solution and the peroxidase content per well assayed using $100 \mu \mathrm{l}$ orthophenylene diamine $1 \mathrm{mg} / \mathrm{ml}$ (Dako, High Wycombe, Bucks) as substrate. The reaction product was terminated after five minutes incubation in the dark at room temperature by the addition of $100 \mu \mathrm{l} 1 \mathrm{M}$ sulphuric acid. The coloured reaction product was read at $492 \mathrm{~nm}$ in a multiscan plate reader within 30 minutes. The plate was washed four times with absolute methanol and air dried at $37^{\circ} \mathrm{C}$ for three hours the determination of cellular protein/well. This was performed before a modification of the Bradford technique. ${ }^{17}$ Briefly $30 \mu \mathrm{l}$ Bradford reageant (Biorad laboratories, Watford, Herts), was added to each well and plate shaken for 30 minutes. $120 \mu \mathrm{l}$ distilled water was added to each well and the plate further shaken for 30 minutes. The reaction product was assayed in a multiscan spectrophotometer at $595 \mathrm{~nm}$. HLA-DR induction/cell was thus expressed as $\mathrm{OD}_{492} \mathrm{~nm} / \mathrm{OD}_{595} \mathrm{~nm}$. Each result was performed in quintuplicate and the results expressed as mean (standard deviation).

\section{CHARACTERISATION OF CYTOKINE}

HIGH PERFORMANCE LIQUID CHROMATOGRAPHY Active supernatants were pooled, desalted by elution from a Sephadex-G25 column and eluted with $0.1 \quad M$ ammonium carbonate, and lyophilised. The lyophilate was reconstituted with a minimum volume of phosphate buffered saline $(0.13 \mathrm{M} \mathrm{pH} \mathrm{7.4)}$ and spun in a 'microcentaur' bench top centrifuge. The supernatant was then applied in a volume of $500 \mu \mathrm{l}$ aliquots onto a TSK G2000SW (Pharmacia-LKB, 'Blue column' Milton Keynes.) gel chromatography column and eluted with phosphate buffered saline buffer using an LKB HPLC pump 2150. Forty fractions of $0.45 \mathrm{ml}$ were collected.

\section{PHYSICOCHEMICAL CHARACTERISTICS}

Pooled active supernatant was passed onto a $5 \mathrm{ml}$ Sephadex G25 column by Pasteur pipette that had been equilibrated with $0 \cdot 1 \mathrm{M}$ glycine buffer $\mathrm{pH} 2$ and eluted with phosphate buffered saline after five minutes, one hour, six hours and 24 hours by the manual addition of buffer to the column.

Active supernatant was heated to $100^{\circ} \mathrm{C}$ for five minutes and aliquots tested before and after treatment.

Active supernatant was incubated at room temperature for 30 minutes with a sheep antiserum to human interferon- $\gamma(\mathrm{H} 53$, - a kind gift of Dr A Meager, National Institute for Biological Standards and Controls, Potter's Bar, Herts). 


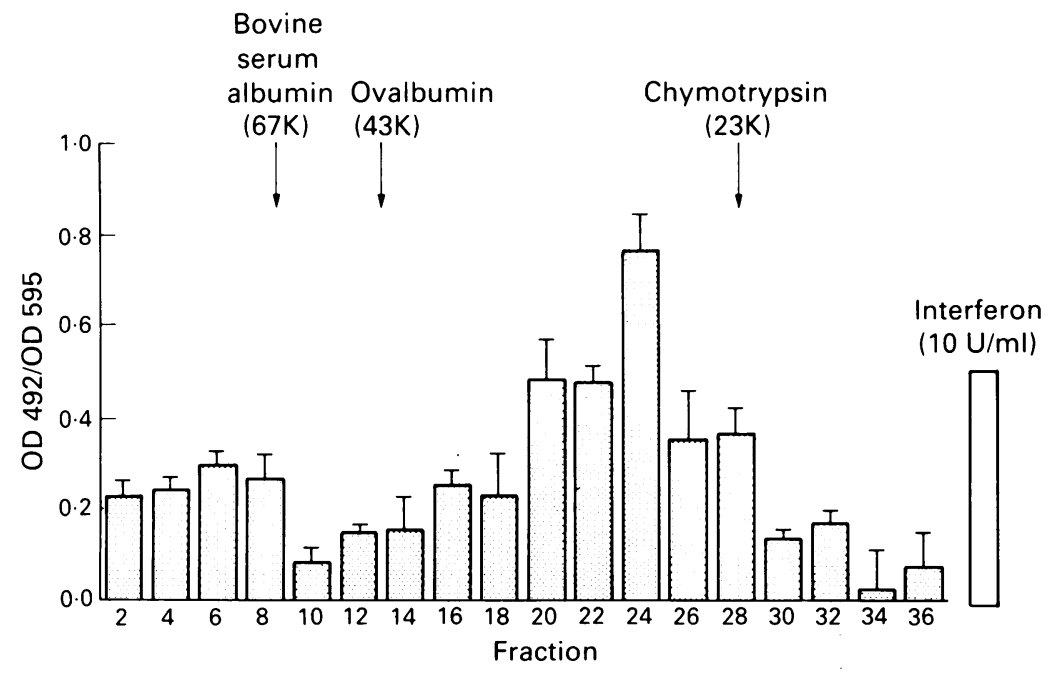

Figure 5: $H L A-D R$ induction $(S D)$ by high performance liquid chromatography gel fractions of poded culture supernatants.

\section{Results}

INDUCTION BY INTERFERON- $\gamma$ HT -29 cells could be induced to express HLADR molecules in a dose dependent fashion (Fig 1). Maximal expression occurred at a dose of 10 $\mathrm{U} / \mathrm{ml}$ interferon- $\gamma$. Higher doses produced a decrease in the amount of cellular protein/well in the ELISA and immunohistochemical studies confirmed that higher doses of interferon- $\gamma$ did not cause an increase in expression but a significant cytopathic effect was exerted (Fig 2a, b).

\section{INDUCTION BY MUCOSAL MONONUCLEAR CELL CULTURE SUPERNATANTS}

Supernatants obtained from the culture of unstimulated mucosal cells did not produce any detectable induction of HLA-DR molecules despite the assay being able to detect $2 \mathrm{U} / \mathrm{ml}$ interferon- $\gamma$. The supernatants obtained from the culture of phytohaemagluttinin stimulated cells all induced detectable quantities of HLADR molecules, but there was no evidence of either increased or decreased production of cytokine differences between patients with ulcerative colitis and Crohn's disease and controls (Fig 3). Phytohaemagglutinin alone did not induce class II antigen expression.

Figure 6: Abrogation of $H L A-D R$ induction by anti-interferon- $\gamma$ antiserum.

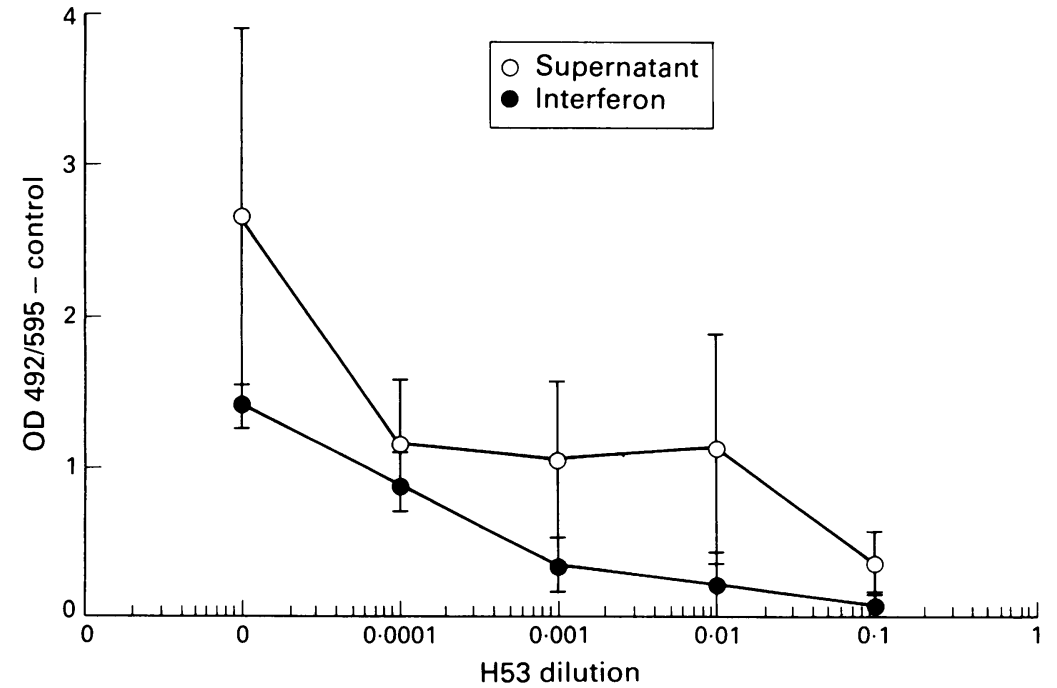

PHYSICOCHEMICAL CHARACTERISTICS

Exposure of the supernatants to $\mathrm{pH} 2$ or boiling for 30 minutes destroyed all class II inducing ability (Fig 4). The testing of individual fractions generated by the gel column suggested that the molecular weight of the active fraction was in the region of $20-25 \mathrm{kD}$ (Fig 5).

Incubation of the pooled supernatant with antiserum to interferon- $\gamma$ resulted in abrogation of class II induction. At a dilution of the antiserum of 1:100 class II induction was not detectable. The abrogation paralleled that seen with interferon- $\gamma$, suggesting that there was not an agent other than interferon- $\gamma$ present in the supernatant that induced class II expression (Fig 6).

\section{Discussion}

This work confirms the work of others that human colonic epithelial cell line can be induced to express HLA class II proteins by recombinant interferon- $\gamma .{ }^{18}$ This occurs in a dose dependent manner up to a concentration of $10 \mathrm{U} / \mathrm{ml}$. Higher concentrations of interferon- $\gamma$ produce a significant cytopathic effect. These concentrations are much lower than have previously observed to be effective. ${ }^{18}$ However previous studies employed a plasmid derived recombinant interferon- $\gamma$ whereas the product employed here was a culture supernatant of a Chinese hamster ovary cell line transfected with the human interferon- $\gamma$ gene, had thus undergone eukaryotic glycosylation and hence potentially different biological activities.

Supernatants from unstimulated mucosal mononuclear cell culture did not produce any significant induction of epithelial class II molecules whereas after phytohaemagglutinin stimulation a significant amount was induced. Spontaneous and stimulated interferon- $\gamma$ production by lamina propria lymphocytes in Crohn's disease has recently been studied. ${ }^{19}$ Using an antiviral bioassay for interferon activity and antisera to interferons $\alpha$ and $\beta$, spontaneous production of interferon- $\gamma$ was observed in Crohn's disease. It is possible that the epithelial cell HLA-DR induction assay is less sensitive for detecting interferon activity than the antiviralbioassay which may explain the differences between these results. No significant differences in HLA-DR induction were obtained using supernatants derived from patients with ulcerative colitis, Crohn's disease. or controls.

The lack of class II induction by cells isolated from inflamed tissue may be considered surprising as the epithelium in cases of inflammatory bowel disease is strikingly HLA-DR positive, ${ }^{12}$ but is in accord with observations on interferon- $\gamma$ production by isolated mucosal mononuclear cells. ${ }^{20}$ Isolating the viable cells from inflamed tissue, however, may selectively deplete those cells that have been activated and are actively synthesising cytokines or the population of cells responsible for in vivo class II induction are rendered effete by the in vitro isolation procedures. ${ }^{2122}$ Furthermore the mucosal mononuclear cell population in inflammatory bowel disease differs from non-inflamed mucosa, and comparisons of cytokine production are therefore meaningless." 
There is a debate about spontaneous mucosal mononuclear cells production of interferon- $\gamma \cdot{ }^{19} 20$ Stimulation of mucosal mononuclear cells by PHA or recombinant interleukin-2-, however, has been shown to induce production of interferon- $\gamma .{ }^{20}$ In these studies decreased amounts of cytokine inducing monocyte HLADR and interferon- $\gamma$ were produced by cells isolated from patients with inflammatory bowel disease. At first sight the results presented here may seem to be discordant with those of Ouyang et al, but the methodology used is quite different. The experiments that are described here quantify the induction of epithelial class II HLA molecules, not the amount of interferon- $\gamma$.

There may be significant amounts of interferon- $\alpha$ or interferon- $\beta$ activity in the supernatant which is indistinguishable from interferon- $\gamma$ in a bioassay.

Ouyang et al used monocytes as model cells for class II induction, and there may be differences between monocyte and epithelial cell lines in induction of class II HLA molecules. There is evidence that many cytokines including interleukin-4, granulocytes macrophage colony stimulating factor and tumour necrosis factor- $\alpha$ may act to increase class II molecule expression, ${ }^{23}$ and synergism between interferon- $\gamma$ and tumour necrossis factor- $\alpha$ has been shown for HT-29 cells. ${ }^{2+25}$

The immunohistological evidence does not suggest that there is a defect in epithelial class II induction in the colon. All the studies reported thus far show extensive epithelial class II induction in ulcerative colitis and Crohn's disease and no qualitative difference from induction seen in inflammatory controls. ${ }^{2125}$

The biological and physicochemical properties of the factor in the supernatants are consistent with it being interferon- $\gamma$. Human interferon- $\gamma$ is usually shown to have a molecular weight of about $55 \mathrm{kD}$, and this has been found to be dimeric with components of 20 and $25 \mathrm{kD} .{ }^{26}$ The activity in the supernatants is acid labile, has a molecular weight of about $22 \mathrm{kD}$, and is completely neutralised by antiserum to human interferon- $\gamma$. Thus it is possible that the monomeric forms are being detected in these fractions.

Unlike studies using circulating lymphocytes we could not detect any evidence of any class II including factor other than interferon- $\gamma \cdot{ }^{27}$ Several explanations for this difference are possible. The assay of class II molecules may be too insensitive, although it was possible to detect the effect of 2 $\mathrm{U} / \mathrm{ml}$ interferon- $\gamma$ above background. Epithelial cells may not be susceptible to the same range of cytokines that induce class II HLA molecules on circulating $\mathrm{T}$ cells. It is probable that mucosal mononuclear cells do not produce the same range of cytokines as produced by the circulating mononuclear cell population.

The responses measured here may be a selective in vitro response to phytohaemagluttinin and may not represent the in vivo situation.

In conclusion, mucosal mononuclear cells of both 'normal' and inflamed colon have the potential to produce cytokines that induce epithelial cell class II molecules. These are, however, only produced after mitogenic stimulation of the cells. The cytokine responsible has the characteristics of interferon- $\gamma$.

1 Barclay AN, Mason DW. Induction of la antigen in rat epidermal cells and gut epithelium by immunological stimuli. F Exp Med 1982; 156: 1665-76.

2 Selby WS, Janossy G, Bofill M, Jewell DP. Expression of HLA-DR antigens by colonic epithelium in inflammatory bowel disease. Clin Exp Immunol 1983; 53: 614-8.

3 Spencer J, Finn T, Isaacson PG. Expression of HLA-DR antigens in epithelium associated with lymphoid tissue in the human gastrointestinal tract. Gut 1986; 27 : 153-7.

4 Scott H, Solheim BG, Brandtzaeg P, Thorsby E. HLA-DR like antigens in the epithelium of the small intestine Scand $\mathcal{F}$ Immunol 1980; 12: 77-82.

5 Bland MHC class II expression by the gut epithelium. Immunol Today 1988; 9: 174-8.

6 Mayer L, Schlien R. Evidence for function of la molecules on gut epithelial cells in man. $\mathcal{F}$ Exp Med 1987; 166: 1471-83.

7 Bland PW, Warren LG. Angtigen presentation by epithelial cells of the rat small intestine. I. Kinetics, antigen specificity and blocking by anti la antisera. Immunology 1986; 58: 1-7.

8 Bland PW, Warren LG. Antigen presentation by epithelial cells of the rat small intestine. II. Selective induction of cells of the rat small intestine. II. Selective
suppressor T cells. Immunology 1986; 58: 9-14.

9 Kaiserlian D, Vidal K, Revillard J-P. Murine enterocytes can present soluble antigen to specific class II restricted CD4 + T cells. Eur F Immunol 1989; 19: 1513-6.

10 Mayer L, Eisenhardt D. Lack of induction of suppressor T cells by intestinal epithelial cells from patients with inflammatory bowel disease. $\mathcal{F}$ Clin Invest 1990; 86: 1255-60.

11 Lowes JR, Jewell DP. Immunology of inflammatory bowel disease. Semin Immunopathol 1990; 12: 251-68.

12 McDonald G, Jewell DP. Class II antigen (HLA-DR) expression by intestinal epithelial cells in inflammatory disease. F Clin Pathol 1987; 40: 312-7.

13 Fais S. Pallone F, Squarcia O, Biancone F, Ricci P, Paoluzi P, et al. HLA-DR antigens on colonic epithelial cells in inflammatory bowel disease: I. Relation to the state of activation of lamina propria lymphocytes and to the epithelial activation of lamina propria lymphocytes and to the epithelial expression of other

14 Hirata I, Austin LL, Blackwell WH, Weber JR, Dobbins WO. Immunoelectron microscopic localization of HLA-DR antigen in control small intestine and control and in inflammatory bowel disease. Dig Dis Sci 1986 31: 317-30.

15 Cerf-Bensussan N, Quaroni A, Kurnick JT, Bhan AK. Intraepithelial lymphocytes modulate la expression by intestinal epithelial cells. F Immunol 1984; 132: 2244-52.

16 Bookman MA, Bull DM. Characteristics of isolated intestinal mucosal lymphoid cells in inflammatory bowel disease. Gastroenterology 1979; 77: 503-10.

17 Baumgarten $\mathrm{H}$. A simple microplate assay for the determination of cellular protein. F Immunol Methods 1985; 82: 25-37.

18 Sollid LM, Gaudernack G, Markussen G, Kvale D, Brandtzaeg $P$, Thorsby E. Induction of various HLA class II molecules in human colonic adenocarcinoma cell line. Scand $\mathcal{F}$ Immunol 1987; 2: 175-80

19 Fais S, Capobianchi MR, Pallone F, Marco P Di, Boirivant M, Dianzani F, et al. Spontaneous release of interferon- $\gamma$ by intestinal lamina propria lymphocytes in Crohn's disease. Kinetics of in vitro response to interferon- $\gamma$ inducers. Gut 1991; 32: 403-7.

20 Quyang Q, El-Youssef M, Yen-Lieberman B, Sapatnekar W, Youngman KR, Kusugami K, et al . Expression of HLA-DR antigens in inflammatory bowel disease mucosa. Role of intestinal lamina propria mononuclear cell derived interferon- $\gamma$. Dig Dis Sci 1988; 33: 1528-36.

21 Bland PW, Richens ER, Britton DC, Lloyd JV. Isolation and purification of human large bowel mucosal lymphoid cells: effect of separation technique on functional characteristics. Gut 1979; 20: 1037-46.

22 Selby WS, Janossy G, Bofill M, Jewell DP. Intestinal lymphocyte populations in inflammatory bowel disease: an analysis by immunohistological and cell isolation techniques. Gut 1984; 25: 32-40.

23 Gerrard TL, Dyer DR, Mostowski HS. IL-4 and granulocytemacrophage colony stimulating factor selectively increase HLA-DR and HLA-DP antigens but not HLA-DQ antigens on human monocytes. F Immunol 1990; 144: 4670-4.

24 Kvale D, Brandtzaeg P, Lovhaug D. Up-regulation of the expression of secretory component and HLA molecules in a human colonic cell line by tumour necrosis factor- $\alpha$ and gamma interferon. Scand f Immunol 1988; 28: 351-7.

25 Arnaund-Battandier F, Cerf-Bensussan N, Amsellem R, Schmitz J. Increased HLA-DR expression by enterocytes in Schmitz J. Increased HLA-DR expression by enterocytes in
children with celiac disease. Gastroenterology 1986; 91: 1206-12.

26 Yip YK, Barrowclough BS, Urban C, Vilcek J. Molecular weight of human gamma interferon is similar to that of other human interferons. Science 1982; 215: 411-3.

27 Groenewegen G, de Ley M, Jeunhomme GMAA, Buurman WA. Supernatants of human leucocytes contain mediator, different from interferon- $\gamma$, which induces expression of $M H C$ class II antigens. $\mathcal{F}$ Exp Med 1986; 164; 131-43. 